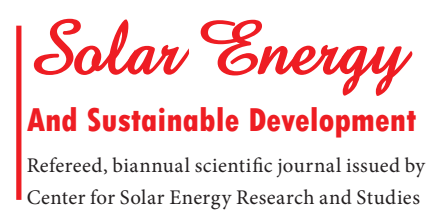

\title{
Wind Energy Resources Estimation and Assessment For AL-Maqrun Town - Libya
}

\author{
Farag Ahwide $^{1}$, Anwar Ismail ${ }^{2}$ \\ ${ }^{1}$ Omar Al-Mukhtar University - Libya - Faculty of Engineering, \\ e-mail: farag.ahwide@omu.edu.ly \\ ${ }^{2}$ Omar Al-Mukhtar University - Libya - Faculty of Arts and Sciences \\ e-mail: Anwar.ismail@omu.edu.ly
}

\begin{abstract}
Fossil fuels (Natural gas, heavy and light oil) are considered the main sources for electricity generation in Libya. Libya's electricity demand is growing at a rapid rate and the country will require significant additional capacity in the coming years due to the development of all sectors of life and the improvement of individuals' life quality, without taking into account the rationalization of electricity consumption. The main reason for this is that Libya has a very high energy subsidy, especially the tariff set by the Libyan state for the price per kilowatt-hour for electricity sector. The heavily subsidized electricity price for household currently stands at (20 dirham's/kilowatt-hour) compared to (100 dirham's/kilowatt-hour), as the domestic price of fuel cost, and in return (450 dirham's/kilowatt-hour) as the electricity cost of fuel in international prices. In order to reduce the deficit and the ongoing balancing in energy demand with the amount of generation of available capacity it is necessary to study all electrical systems for the future, the most important of which are wind energy and solar energy projects to meet a significant part of this demand, and to reduce, as much as possible, the carbon dioxide emissions. This paper deals with the wind data processing at the site coupled with the city and its relationship to electricity generation. It presents long term wind data analysis, in terms of averages of ten minute values of wind speed were used to get yearly mean values for a period of 1 year, between 04/11/2002 and 30/12/2003. Most frequent wind directions are NW, N, NNW and WNW. They represent about 50\%, followed by E, ESE and SE. In general, East and SE winds are relatively frequent but weak at the same time. The most powerful directions are NW, WNW, W and NNW which by far - represent about 46\% of the expected power, followed by N. It should be noted that the high frequency of north direction winds that come from the desert can cause a high frequency of dust episodes. This
\end{abstract}


fact should be taken into consideration in order to take appropriate measures to prevent wind turbine deterioration. The annual energy yield and wind direction were evaluated for AL-Magrun town, considering wind turbines ranging between 1.65 MW and $2 \mathrm{MW}$ (power curve considering air density $1.225 \mathrm{~kg} / \mathrm{m}^{3}$ ). The wind turbine (Gamesa 90/2000) recorded the highest values, equaling (6.05GWh,3023Eqh) and (M. Torres TWT 1.65-82 ) equaling (4.39 GWh, 2660 Eqh) compared to the rest of the turbines studied. These values encouraged us to take advantage of wind power to achieve economic benefits.

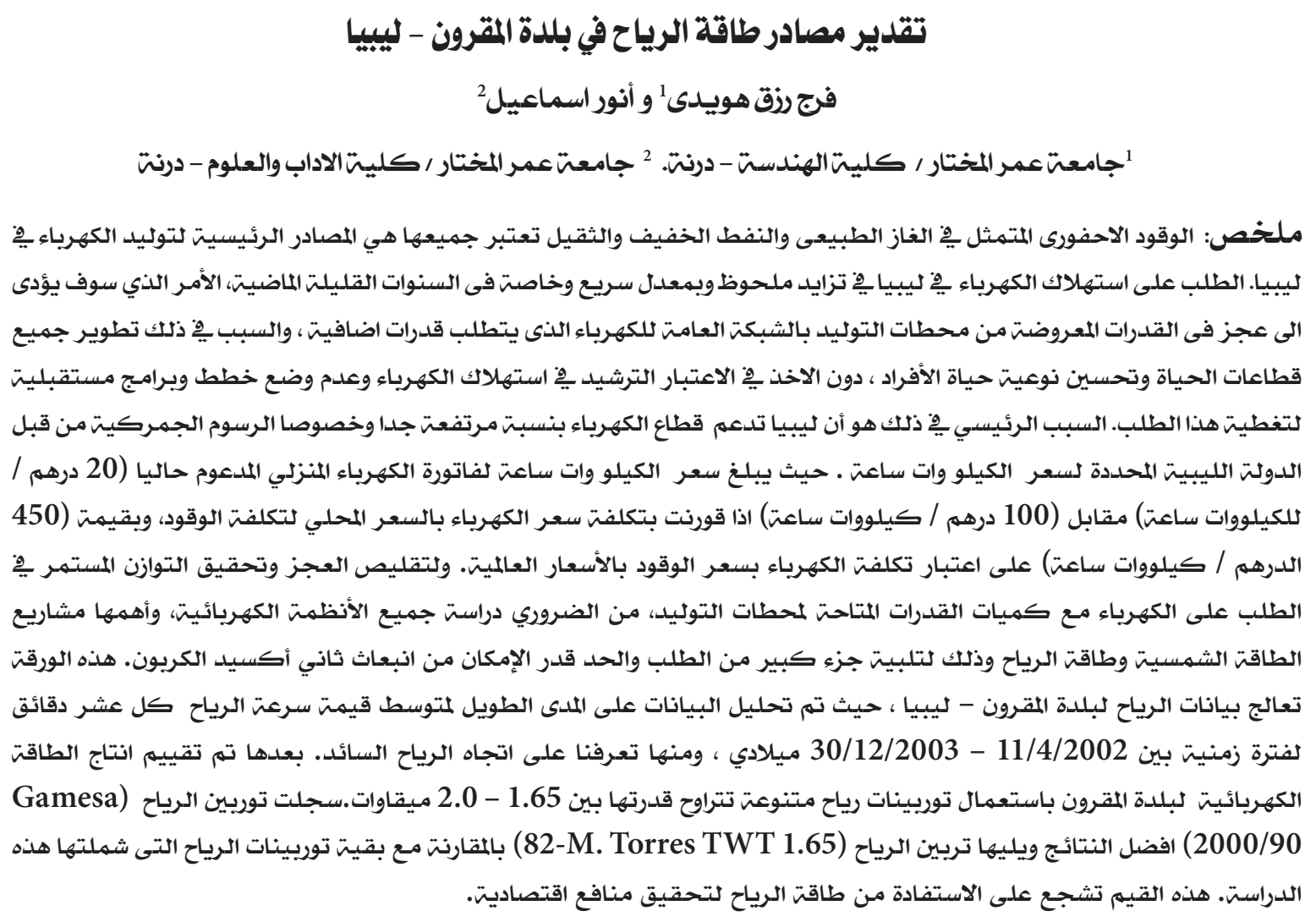

Keywords: wind turbines, wind data, energy yield, technology

\begin{tabular}{ll}
\multicolumn{2}{c}{ Nomenclature } \\
$N$ & north direction \\
NNE & north-northeast direction \\
NE & northeast direction \\
ENE & east-northeast direction \\
$E$ & east direction \\
ESE & east-Southeast direction \\
SE & southeast direction \\
SSE & south-Southeast direction \\
S & south direction \\
SSW & south-Southwest direction
\end{tabular}




\begin{tabular}{|c|c|c|}
\hline$S W$ & southwest direction & \\
\hline$W S W$ & west-Southwest direction & \\
\hline$W$ & west direction & \\
\hline$W N W$ & west- northwest & \\
\hline$N W$ & northwest direction & \\
\hline$N N W$ & north - northwest direction & \\
\hline$N$ & the sample size & \\
\hline L.F & load factor & \\
\hline$C p$ & power coefficient or Betz Limit & \\
\hline$V$ & wind speed, & $m / s$ \\
\hline$V i$ & observation value of wind speed, & $m / s$ \\
\hline$P$ & wind power density, & $W / m^{2}$ \\
\hline$\rho$ & air density, & $\mathrm{kg} / \mathrm{m}^{3}$ \\
\hline Eqh & equivalent hours, & $h$ \\
\hline$P^{\prime}$ & specific power duration, & $W / m^{2}$ \\
\hline$u$ & coefficient of the conventional use of time, & $h / 8760$ \\
\hline E.Y & energy yield, & $k W h / m^{2} / y$ \\
\hline$A$ & swept area, & $m^{2}$ \\
\hline$E_{\text {out }}$ & annual energy output, & $G W h$ \\
\hline
\end{tabular}




\section{INTRODUCTION}

Libya is one of the leading oil exporting countries and it has a great potential of renewable energy resources. So it will be a main objective to increase the production of electricity from renewable energy sources which can reach $10 \%$. Therefore it is necessary to study all electrical systems and the most important of which are solar and wind energy projects to meet a significant part of this demand, and to reduce, as much as possible, the carbon dioxide emissions. The motivation behind this is to significantly reduce the costs of the national electricity production. The aim of this study is to assess the potential wind energy in Libyan coast in AL-Magrun town. The analyzed period contains data since $04 / 11 / 2002$ to 31/12/2003. The Excel work sheet has been generated in order to allow comparisons at different heights:

- Histograms of wind speed at $80 \mathrm{~m}$, $40 \mathrm{~m}, 20 \mathrm{~m}$ and $10 \mathrm{~m}$.

- Estimated wind speed variation with height up to $80 \mathrm{~m}$.

- Wind roses of occurrence, wind speed, power distribution and energy rose at $40 \mathrm{~m}$.

- Estimated wind speed and Weibull distribution at $80 \mathrm{~m}$

- Estimated energy yield using the power curve of a generic wind turbine (V80-2.0MW) Vestas of class I with hub height at $80 \mathrm{~m}$.

\subsection{Climate conditions in Libya.}

Due to the lack of natural barriers, the climate is greatly influenced by the desert to the south and the Mediterranean Sea to the north. The annual average temperature ranges between $19.5 \mathrm{oC}$ in northern Libya and $23.5 \mathrm{oC}$ in the south and total annual precipitation varies from $600 \mathrm{~mm}$ on the coast and $0 \mathrm{~mm}$ in the south.

Semiarid conditions predominate in the AL-Marj and Jaffara plains, and in the southern deserts frequent periods of drought occur. A scorching wind called the "GHIBLI" which is a hot, very dry, sand laden wind which can raise the temperatures in a matter of hours to between $40 \mathrm{oC}$ and $50 \mathrm{oC}$, occasionally blows into the usually humid coastal towns. Extreme temperature and humidity conditions can be observed in Libya. These factors, together with the particular characteristics of desert -especially dust-, must be taken into account by the manufacturers of wind turbines in order to select the suitable model of wind turbine to use and to take appropriate measures to prevent its damage.

\section{DATA AND METHODS}

\subsection{Study area description}

AL-Magrun is a town in the Benghazi District, Cyrenaica region in northeastern Libya. It was formed by the Italian concentration camp for the nomadic tribes that lived in Eastern Libya, and for those in the Libyan resistance movement, during the Italian colonial period.

The study site is situated at geographical coordinates at the intersection of $31^{\circ} 26^{\prime} 30^{\prime \prime}$ $\mathrm{N}$ and $20^{\circ} 09^{\prime} 29^{\prime \prime} \mathrm{E}$, Figure 1. The annual 
average temperature of AL-Maqrun town is $19.9{ }^{\circ} \mathrm{C}$, while the annual precipitation average ranged at $150 \mathrm{~mm}$. A scorching wind called the "GHIBLI" which is a hot, very dry, sand laden wind which can raise the temperatures in a matter of hours to between $40{ }^{\circ} \mathrm{C}$ and $50{ }^{\circ} \mathrm{C}$, occasionally blows into the usually humid coastal towns. The measurements of wind speed showed high potential of wind energy in AL-Maqrun.

\subsection{Data collection}

\section{Details weather data concerning} atmospheric pressure, temperature, humidity, and wind speed as well as the wind direction was measured at AL-Magrun station by using a meteorological mast. The data were recorded each 10 minutes from seven levels beginning from $3.5 \mathrm{~m}$ to $40.4 \mathrm{~m}$ during 2002, Figure 2.

\subsection{Estimation of potential wind resources}

\subsubsection{The mean wind speed}

The mean wind speed is the most commonly used indicator of wind production potential, where it is defined as shown in the following formula [3]:

$$
\mathrm{V}=\frac{1}{\mathrm{~N}} \sum_{\mathrm{i}=1}^{\mathrm{N}} \mathrm{V}_{\mathrm{i}}
$$

Where: $\mathrm{V}$ is the wind speed $(\mathrm{m} / \mathrm{s}), \mathrm{N}$ the sample size, and $V_{i}(\mathrm{~m} / \mathrm{s})$ is the observation value of wind speed.

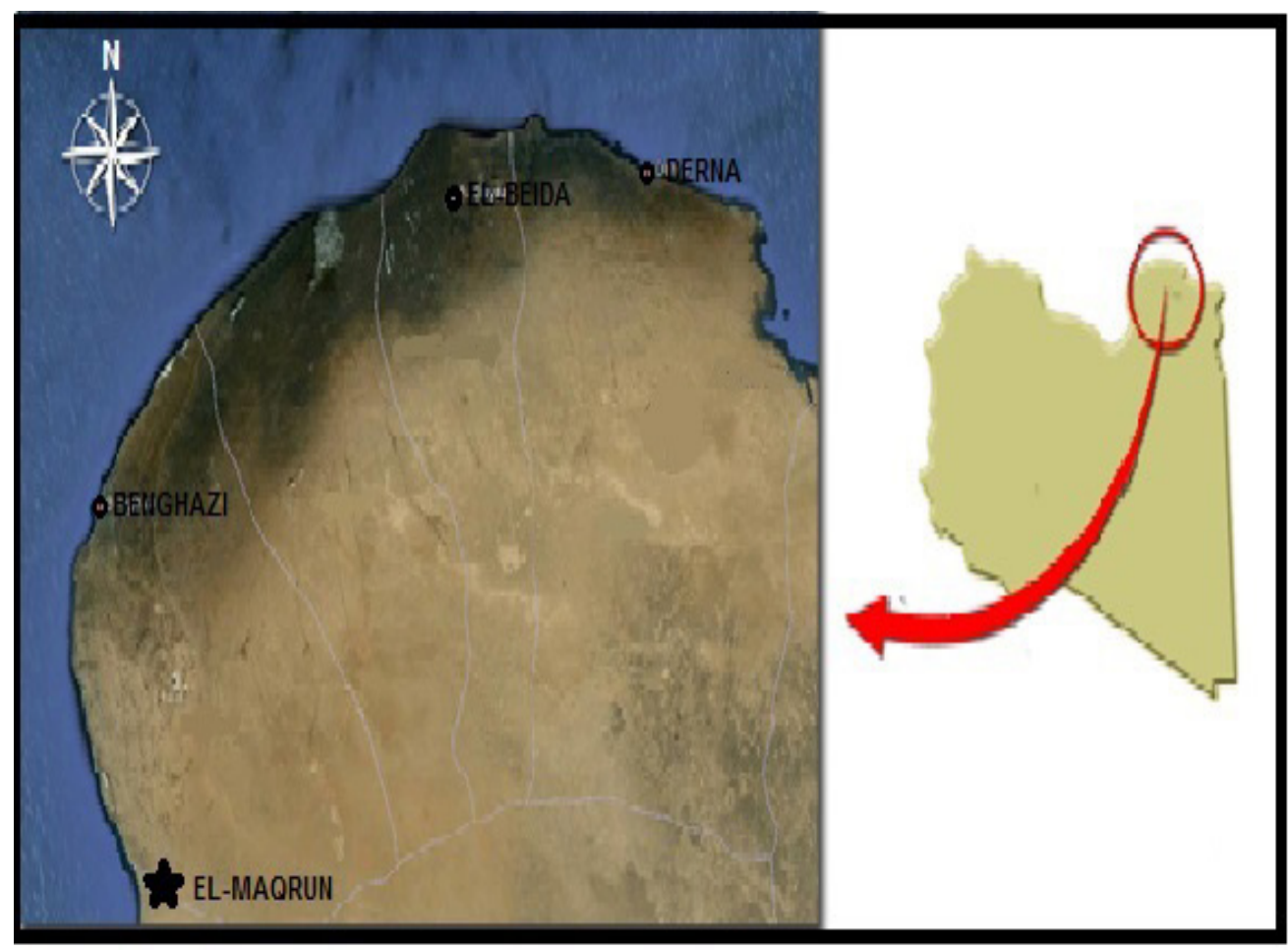

Figure (1). Location of AL-Maqrun in Libya 

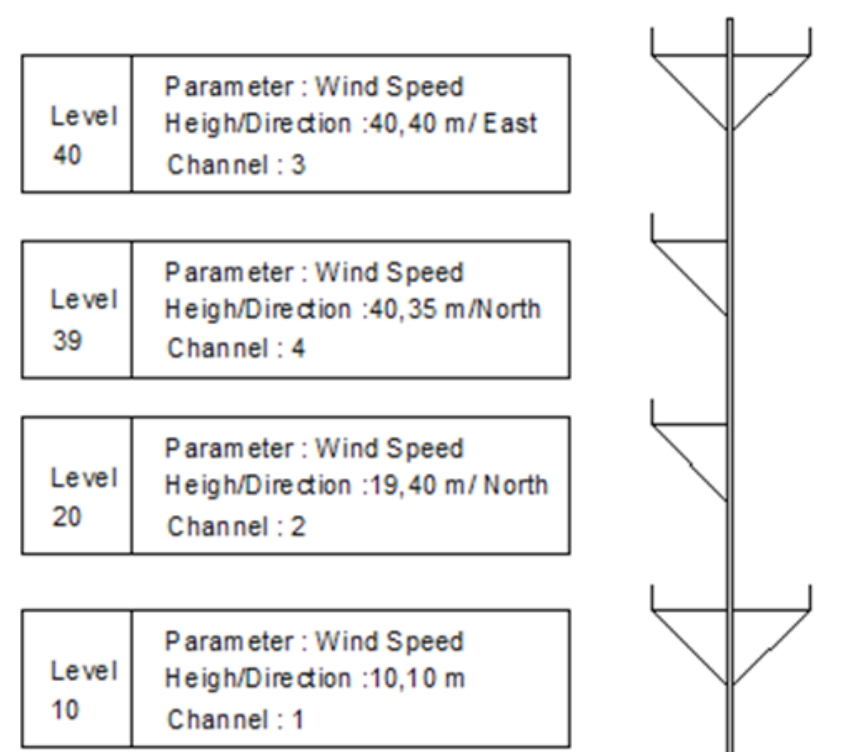

Parameter: Wind Direction Heigh/D irection : $40,5 \mathrm{~m} /$ West Channel: 6

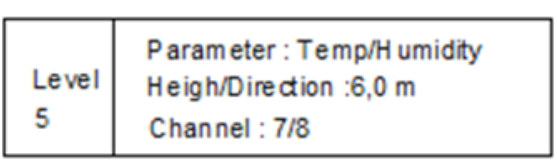

\begin{tabular}{|l|l|}
\hline Level & $\begin{array}{l}\text { Parameter : Barom eter(in side) } \\
\text { Heigh/Dire ction }: 3,5 \mathrm{~m} \\
3\end{array}$ \\
Channel : 9
\end{tabular}

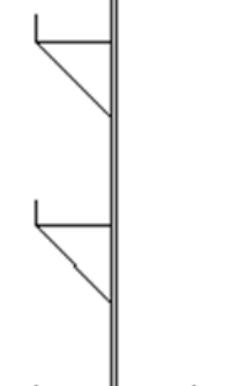

Parameter: Wind Direction Heigh/D irection : $40,5 \mathrm{~m} / \mathrm{Nest}$ Channel: 6

Solar Panel

Heigh/D irection :7,0 m/South

Parameter : Datalogger

Heigh/D irection : $3,5 \mathrm{~m} / \mathrm{N}$ orth

Temperature inside

Figure (2). Meteorological mast in the AL-Maqrun town

\subsubsection{Wind speed variation with height}

The variation in wind speed with elevation influences both the assessment of wind resources and the design of wind turbines. First, the assessment of wind resources over the study area was measured by the anemometer data. Hence, a meteorological mast was established to obtain data concerning the direction and speed of winds at different elevations, starting from $10 \mathrm{~m}$, $20 \mathrm{~m}$, to $40 \mathrm{~m}$. While, the data direction and wind speed at heights $50 \mathrm{~m}, 60 \mathrm{~m}, 70 \mathrm{~m}$ and 80 meters were calculated in the same manner used in the previous research published and submitted by Shata and Hanitsch [4] and Ahwide and Spena [5] .

\subsubsection{Statistical analysis}

All the statistical work and power calculations were performed by using “ WindPRO" software and Excel work sheet .

In order to understand the interaction between the studied parameters, correlation coefficients were calculated to explore the type of existing relations, while regression analyses were utilized to recognize the dependency or not between these parameters. All the statistical work and power calculations was carried by using "WindPRO" software and Excel work sheet Version (2010) and Ahwide's \& Spena method. 


\section{RESULTS AND DISCUSSION REVIEW STAGE}

This section covers the long term annual, seasonal and diurnal variation of mean wind speed; the wind availability in terms of frequency distribution, energy calculations using Excel workbook in wind turbine machines of different rated powers and capacity factor estimation and its variation with wind machine size and hub height. Lastly, the energy output from a different wind turbine of 1.65 and $2 \mathrm{MW}$ installed capacity is discussed with wind size and hub height.

\subsection{Long term wind speed variation}

The long term yearly variation of wind speed provides an understanding of the long term pattern of wind speed and also confidence to an investor on the availability of wind power in coming years. In order to study the annual behavior of the wind speed, averages of ten minute values of wind speed were used to get yearly mean values for a period of 1 year, between 04/11/2002 and $30 / 12 / 2003$. The year-to-year change in the mean wind speed at $10 \mathrm{~m}, 20 \mathrm{~m}, 40 \mathrm{~m}$ and $80 \mathrm{~m}$ above the ground is shown in figures, $3,4,5$ and 6 .

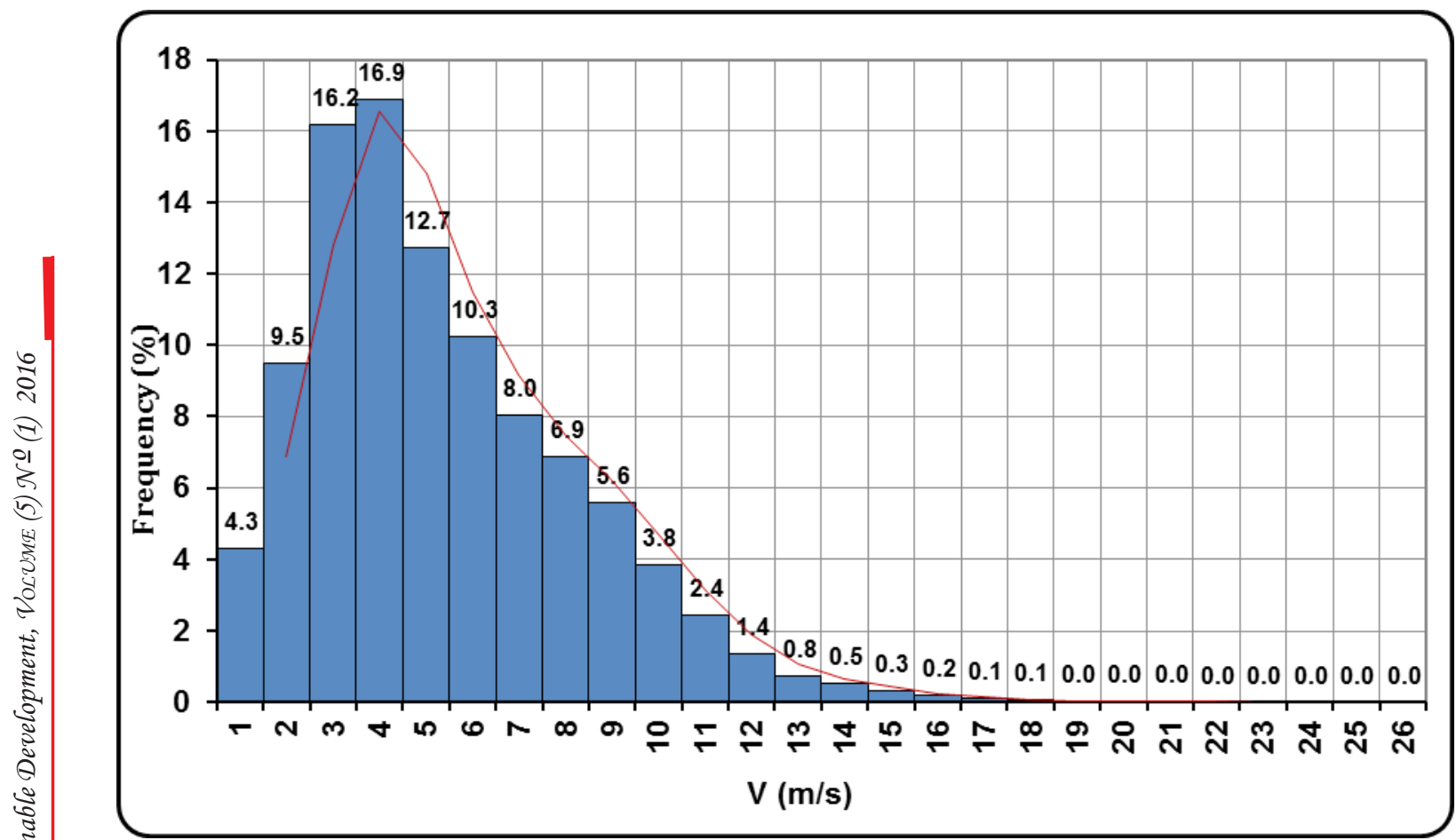

Figure (3). Wind speed distribution at $10 \mathrm{~m}$ height 


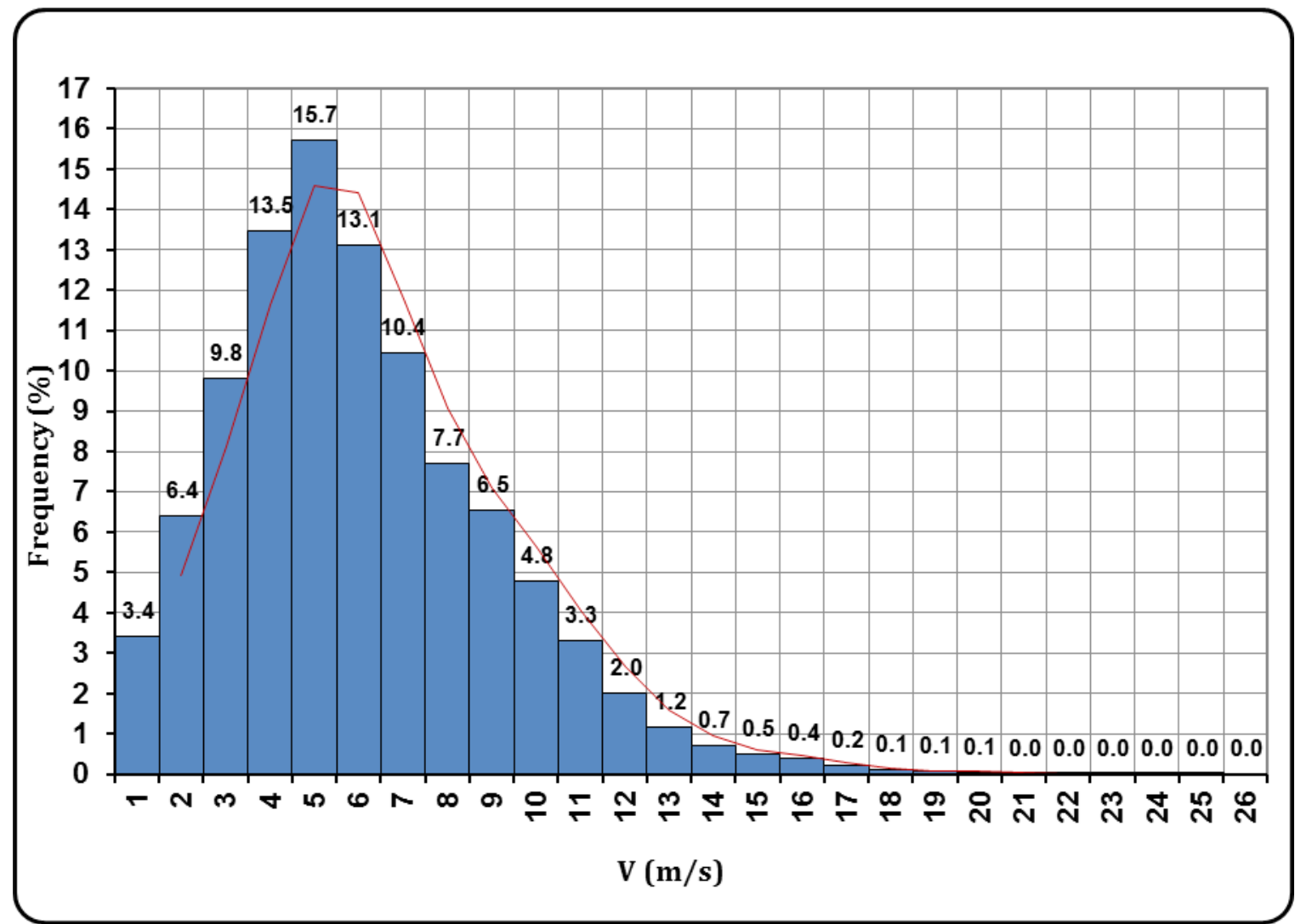

Figure (4). Wind speed distribution at $20 \mathrm{~m}$ height

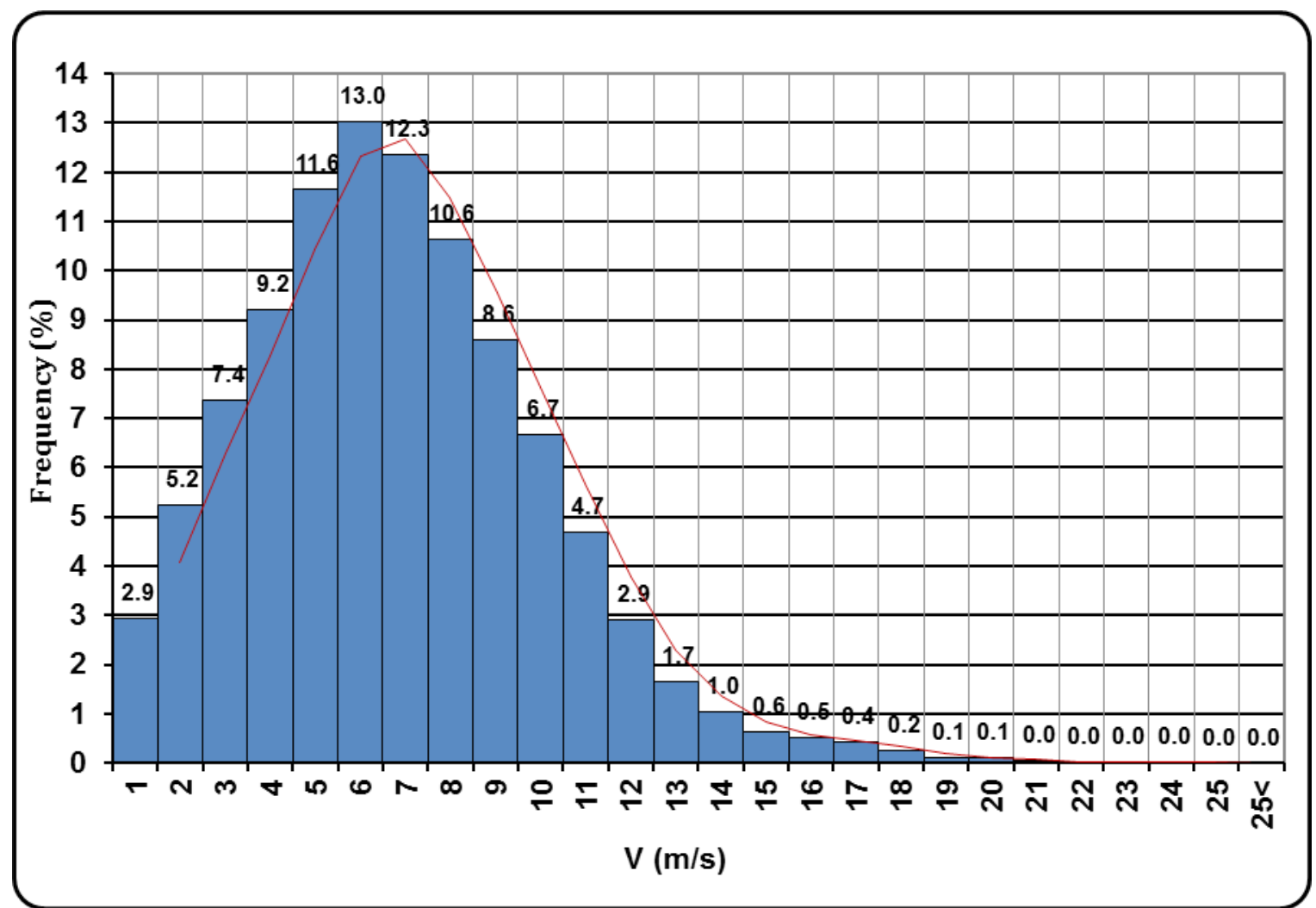

Figure (5) Wind speed distribution at $40 \mathrm{~m}$ height 


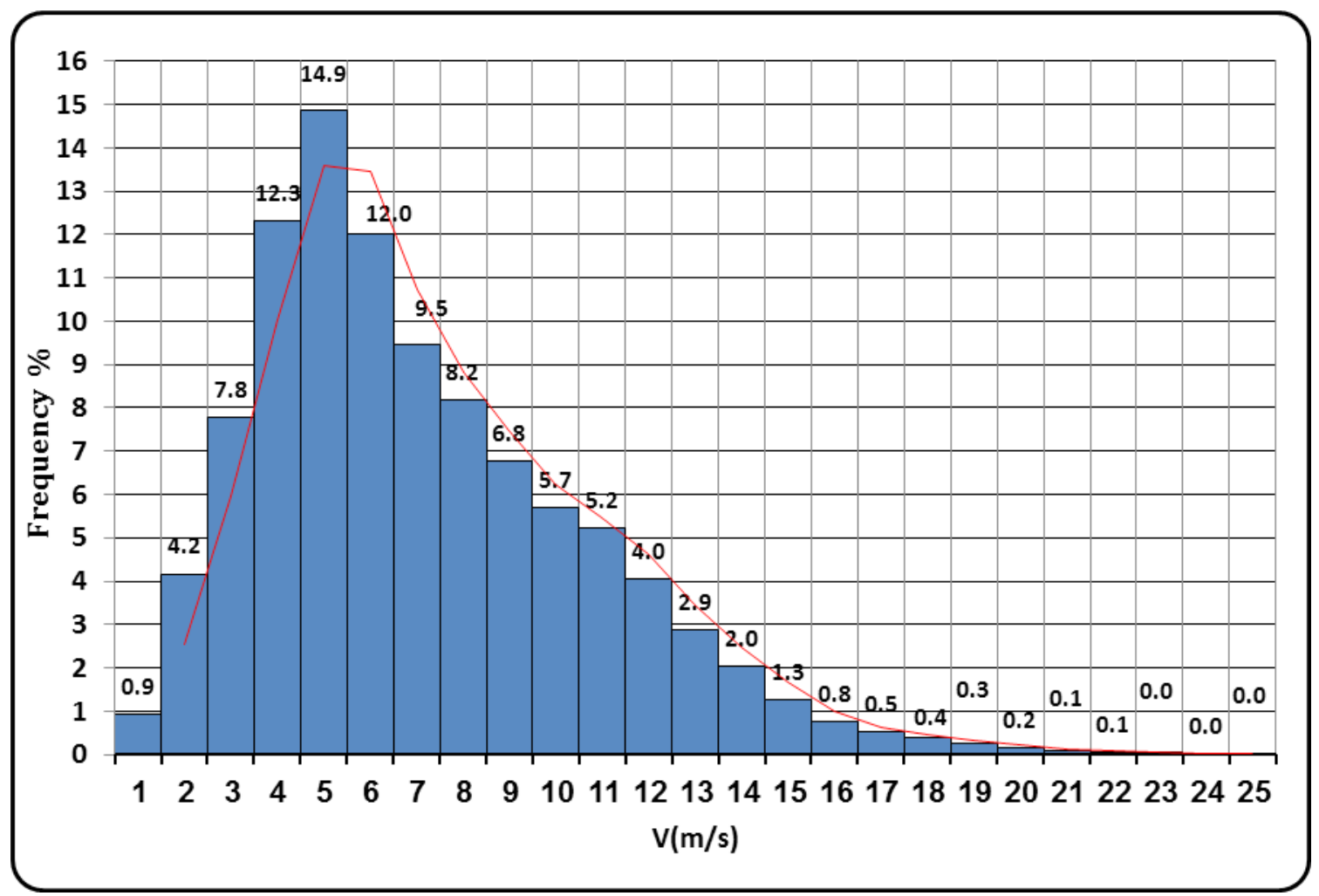

Figure (6). Wind speed distribution of wind speed at $80 \mathrm{~m}$ height

\subsection{Wind availability analysis}

The wind rose provides information about the occurrence of the number of hours or percentage of time during which the wind remained at a certain wind speed in a particular wind direction. Wind roses are constructed using hourly mean wind speed and corresponding wind direction values. Like wind speed, wind roses also vary from one location to another and are known as a form of meteorological fingerprints. Hence, a closelook at the wind rose and understanding its message correctly is extremely important for setting wind turbines. So, if a large share of wind or wind energy comes from a particular direction then the wind turbines should be placed or installed against that direction. Average wind speeds equal to 10 $\mathrm{m}, 20 \mathrm{~m}$ and $40 \mathrm{~m}$ height, and respectively
$5.37 \mathrm{~m} / \mathrm{s}, 6.08 \mathrm{~m} / \mathrm{s}$, and $6.82 \mathrm{~m} / \mathrm{s}$. Highest wind speeds are observed at NNW, followed by NW, WNW, W and ESE sectors. Lowest wind speeds are observed between $\mathrm{N}$ and $\mathrm{E}$ sectors. Most frequent wind directions are NW and NNW. Hence, wind turbines can be installed against these directions. The surface wind at $40 \mathrm{~m}$ are predominantly from $\mathrm{N}$ and NW $34 \%$ ( Figure 7), wind speed at these directions ranged between $4.8 \mathrm{~m} / \mathrm{s}$ to $7.1 \mathrm{~m} / \mathrm{s}$ (Figure 8). On the other hand, especially early in the winter where air flow is dominated by moving depressions so that winds tend to have a western component at AL-Magrun station. In summer when there is less pressure variation, the winds become both more variable and dominated by local conditions. The air flow, from the Sahara Desert; southeast of the country, 
is blowing as a local wind known (Ghibli). This local wind (about 7\%) is hot, dry, and dust-laden wind. It causes very dramatic changes even in a few minutes as associated with high speed ranged between $5.5 \mathrm{~m} / \mathrm{s}$ to $6.9 \mathrm{~m} / \mathrm{s}$. The flow at $\mathrm{E}-\mathrm{NE}$ is constricted (below 5\%) and wind speed ranged between 3.2 to $4.6 \mathrm{~m} / \mathrm{s}$. The most powerful sector is NW (16.3\% of total expected wind energy), followed by $11.9 \% \mathrm{WNW}, 8.8 \% \mathrm{~N}$ and $8.6 \%$ NNW (Figure 9). Also it has been noted that the high frequency of the south direction winds, that come from the desert could cause a high frequency of dust episodes. This fact then, should be taken into account in order to take appropriate measures to prevent wind turbine deterioration.

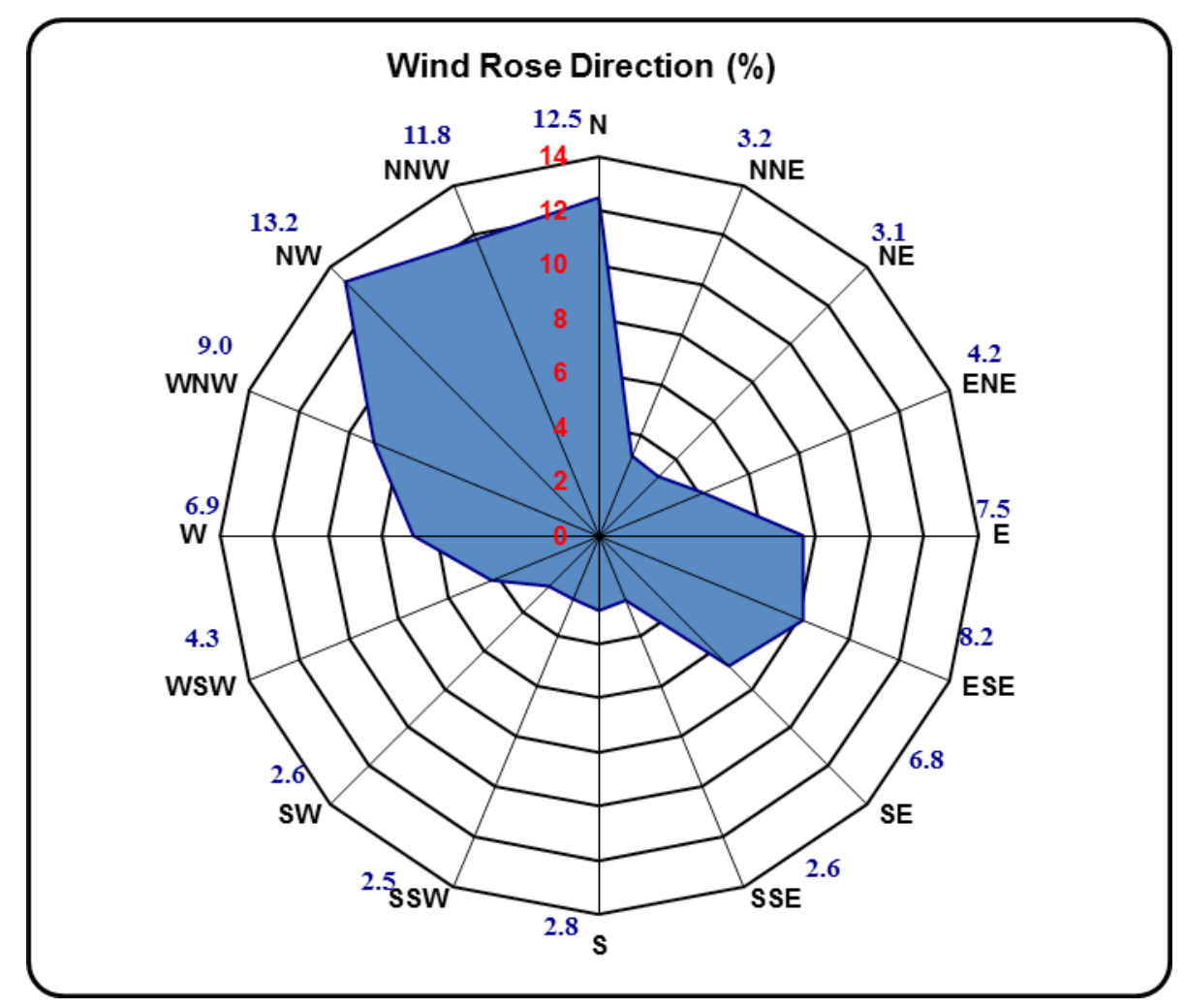

Figure (7). Wind rose direction at $40 \mathrm{~m}$ height (\%) 


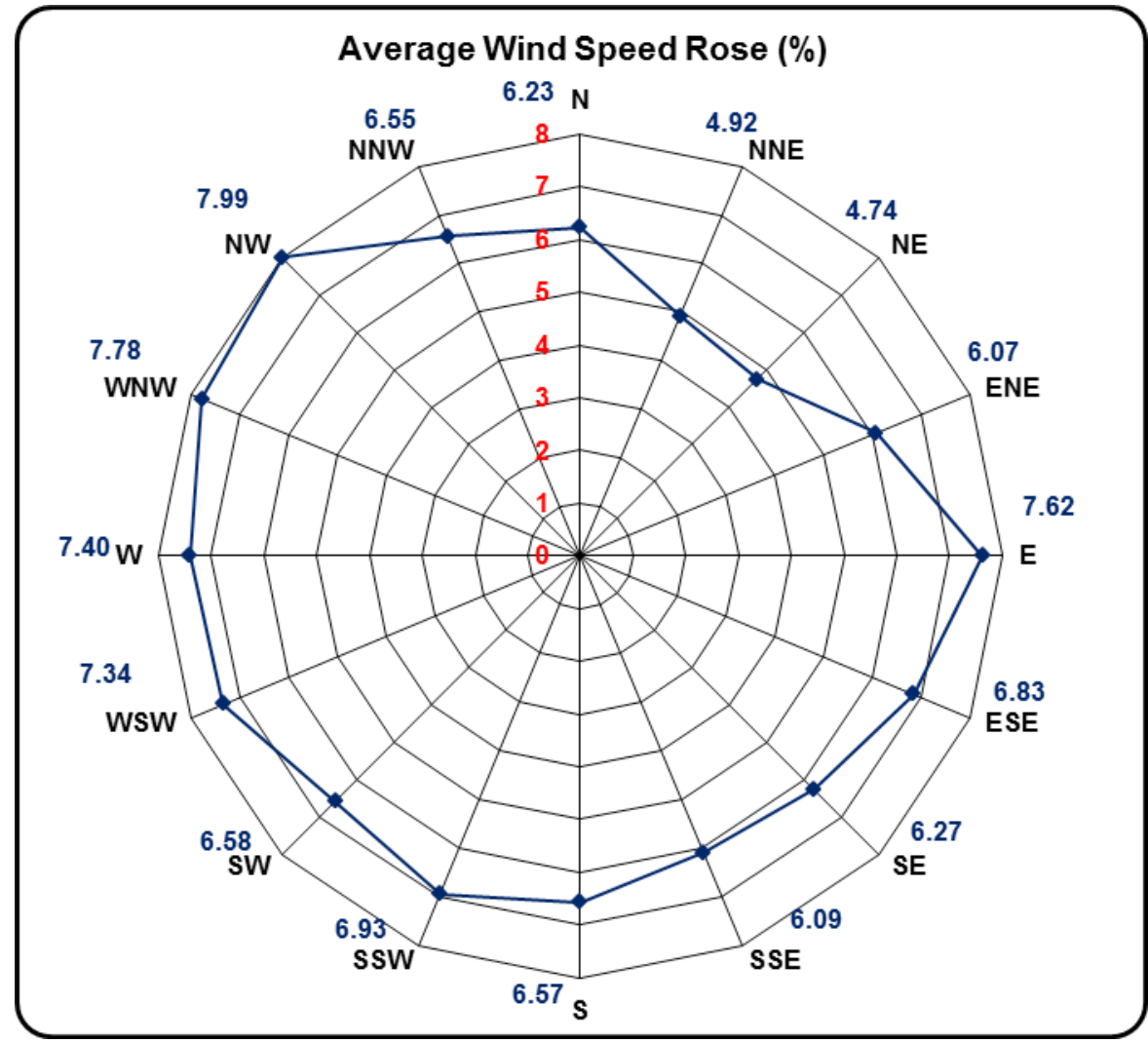

Figure (8). Average wind speed rose at $40 \mathrm{~m}$ heights

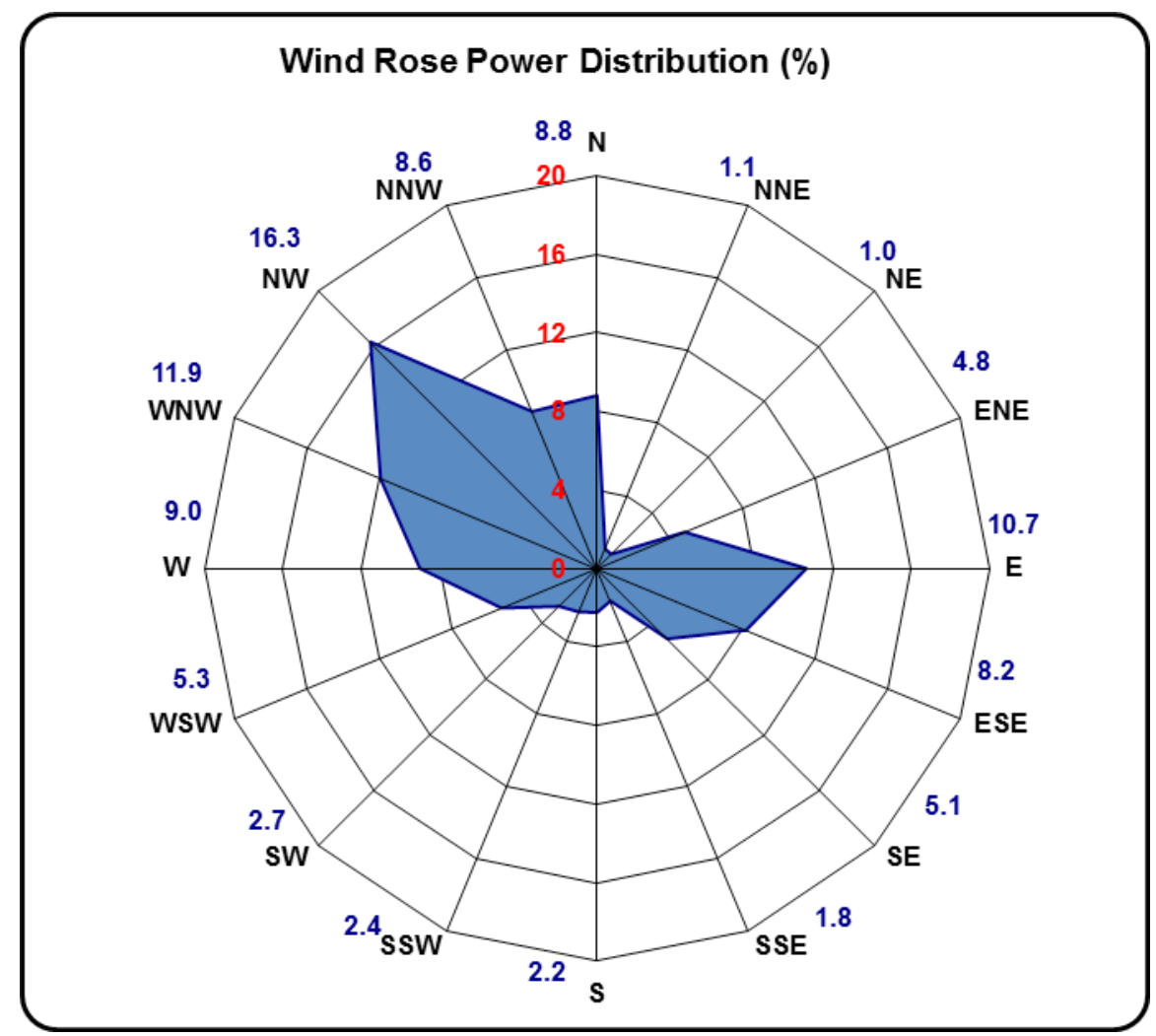

Figure (9). Wind rose power distribution at $40 \mathrm{~m}$ height (\%) 


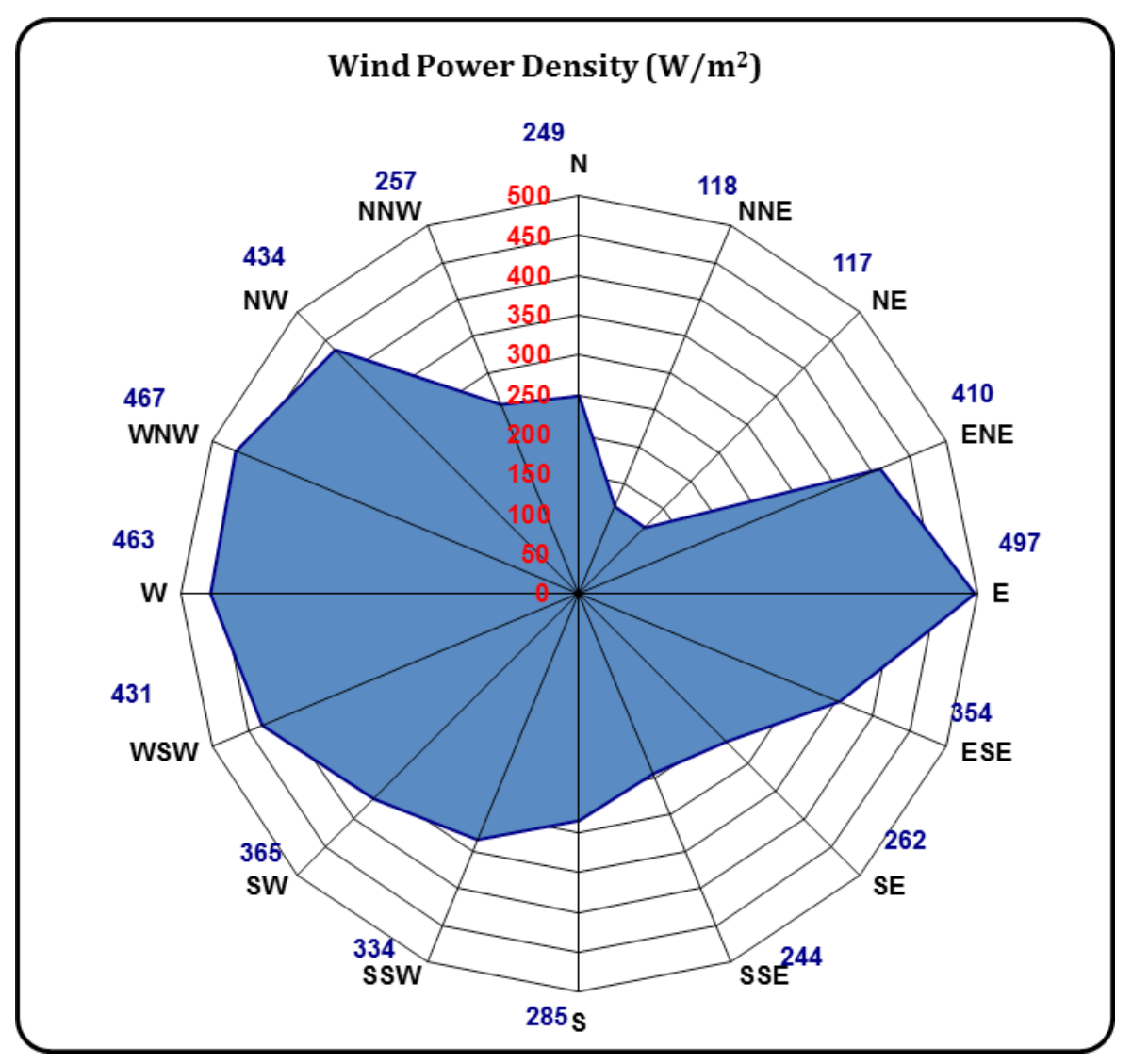

Figure (10) Wind power density at $40 \mathrm{~m}$ height $\left(\mathrm{W} / \mathrm{m}^{2}\right)$

\section{ASSESSMENT OF ANNUAL ENERGY YIELD}

In this study, Ahwide's \& Spena method has been used to evaluate the energy yield and wind statistics for AL-Magrun town[6]. A case study has been used in calculations (V80-2.0MW) Vestas wind turbine:

\subsection{Wind power density}

The wind power density was calculated from equation

$$
P=\frac{1}{2} \rho V^{3}
$$

where $(\rho)$, is the air density

This has rendered possible to design the diagrams of average wind speed duration
(V) (Figure 11) and of the specific power duration (P'), (Figure 12) according to a coefficient of the conventional use of time (u),

$\mathrm{u}(\%)=\frac{\mathrm{h}}{8760}$

where ( $h$ ), is the number of hours in which the value of wind speed are frequented in the year. The annual energy was calculated at $80 \mathrm{~m}$ height based on specification of wind turbine known as Vestas (V80-2.0MW) wind turbine whose main characteristics are shown in Table 2, and its power curve is shown in Figure 13. In these correlation the air density is equal to $\rho=1.225 \mathrm{~kg} / \mathrm{m}^{3}$. The power curve of a industrial wind turbine 
shows the typical trend of the wind speed. of about $\mathrm{V}=4 \mathrm{~m} / \mathrm{s}$ and reached $100 \%$ at speed The power was equal to zero up to a speed $V=16 \mathrm{~m} / \mathrm{s}$ and the cut-out speed is $25 \mathrm{~m} / \mathrm{s}$.

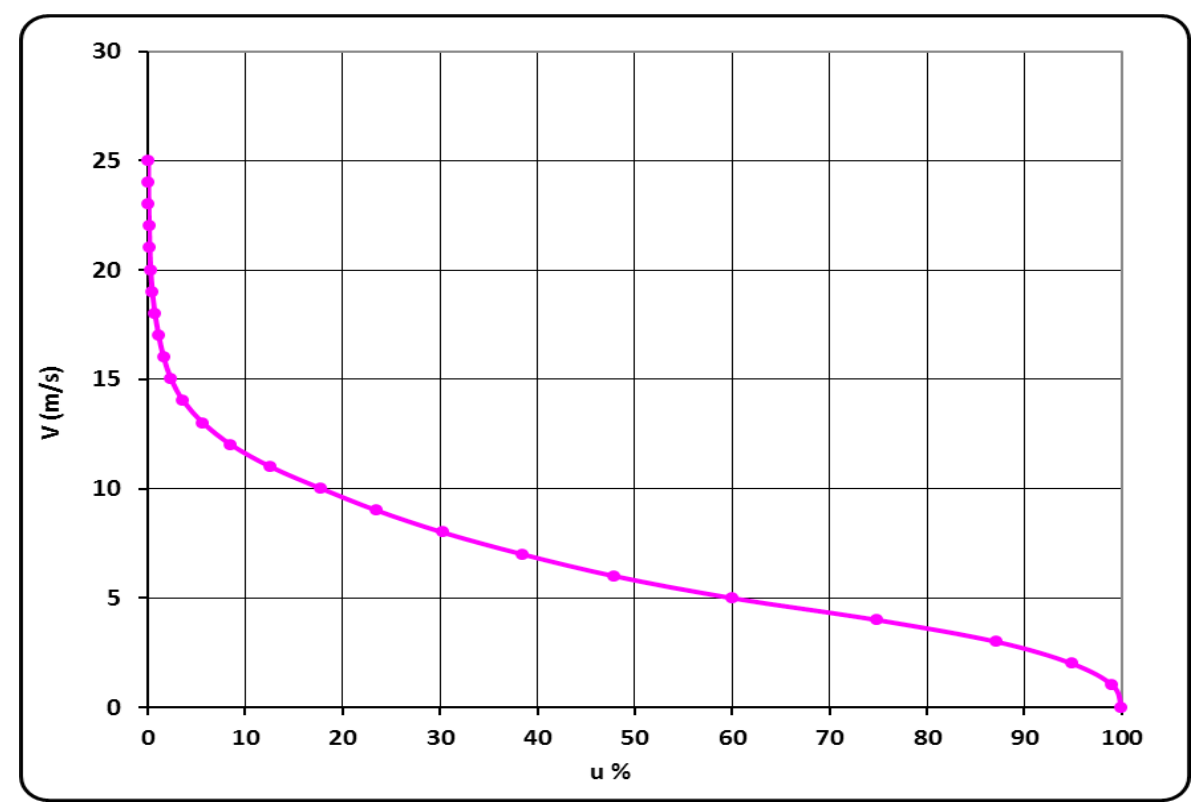

Figure (11). Duration of wind speed, every 10 min, year 2002-2003, El-Maqrun-Libya

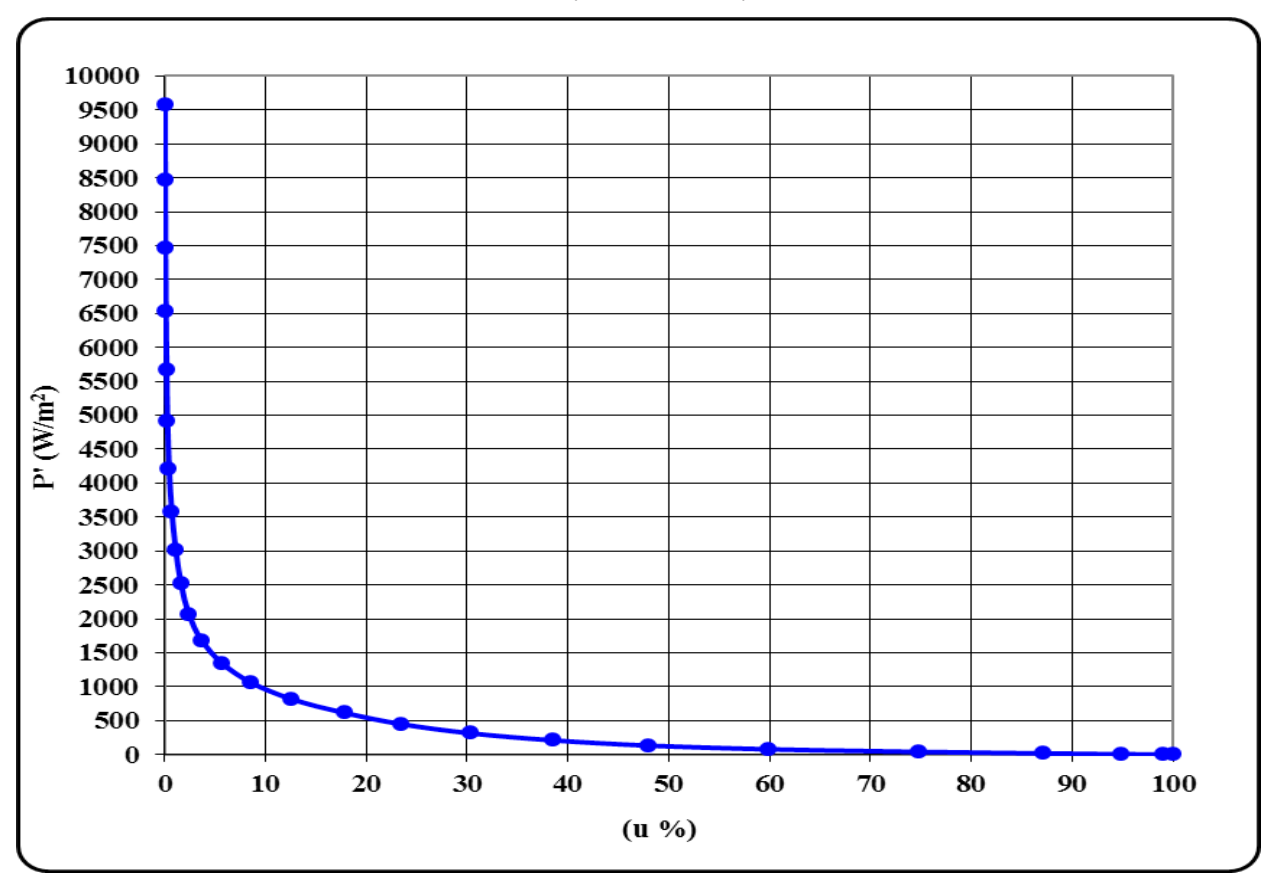

Figure (12). Specific power durations AL-Maqrun- Libya

Table (2). Main characteristics of wind turbine Vestas (V80-2.0MW) [7]

\begin{tabular}{|l|l|}
\hline \multicolumn{2}{|c|}{ Vestas Wind Turbine (V80-2.0MW) } \\
\hline Turbine model & Vestas V80-2.0MW \\
\hline Rated power & $2000 \mathrm{~kW}$ \\
\hline
\end{tabular}




\begin{tabular}{|l|l|}
\hline Swept area & $5027 \mathrm{~m}^{2}$ \\
\hline Rotor diameter & $80 \mathrm{~m}$ \\
\hline Number of blades & 3 \\
\hline Cut-in wind speed & $4 \mathrm{~m} / \mathrm{s}$ \\
\hline Rated wind speed & $16 \mathrm{~m} / \mathrm{s}$ \\
\hline Cut-out wind speed & $25 \mathrm{~m} / \mathrm{s}$ \\
\hline Hub altitude & $80 \mathrm{~m}$ \\
\hline
\end{tabular}

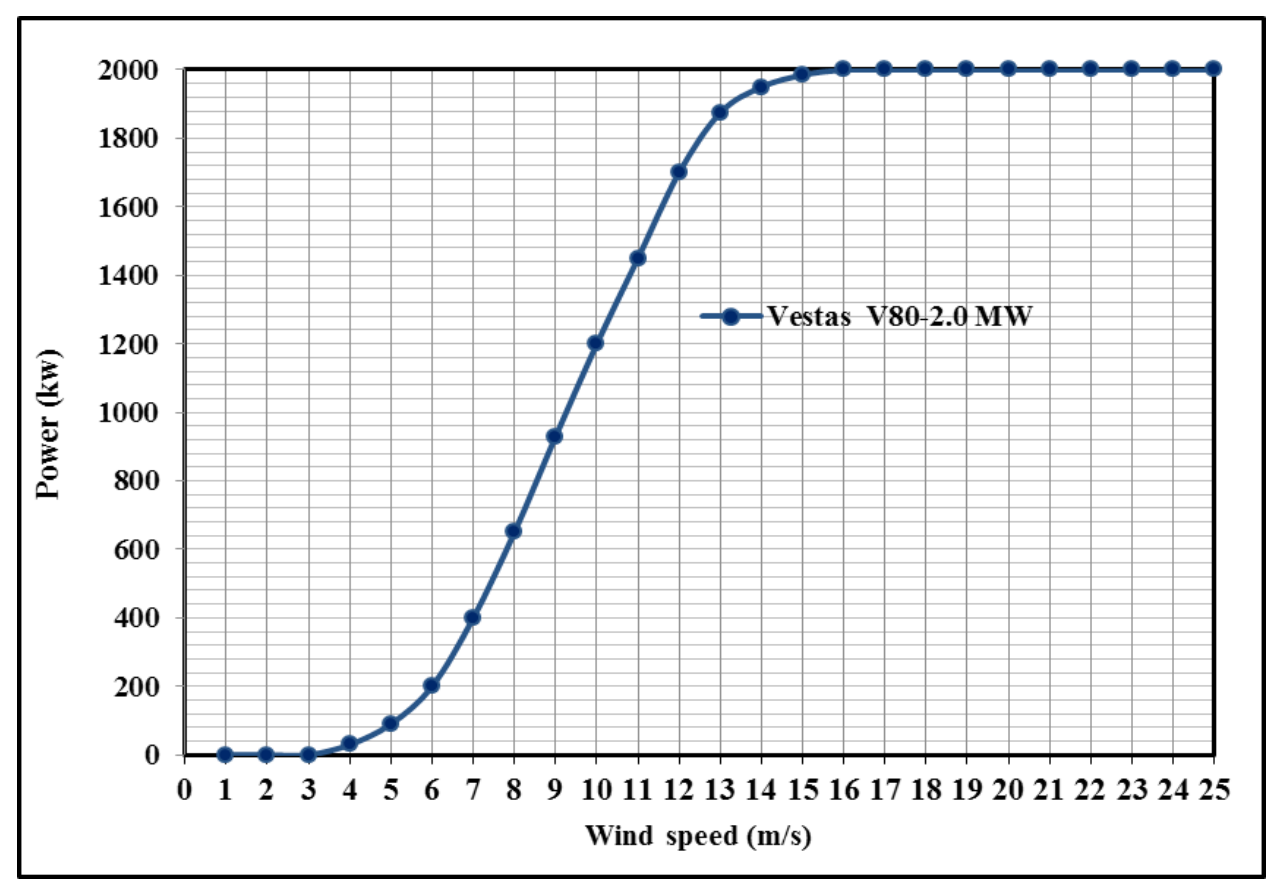

Figure (13). Load factor and power curves of Vestas V80-2.0 MW wind turbine

From the curve of Figure 13 the load factor (LF) was calculated and designed its diagram as in Figure 14, which is defined as the ratio between the instantaneous power and the maximum load of wind turbine, in relation of specific power $\left(\mathrm{P}^{\prime}\right)$, corresponding to each wind speed $(\mathrm{V})$ according to the equation of wind power density. Figure 14 shows the curve of load factor superimposed on the frequency distribution of wind speeds of AL-Maqrun location at $80 \mathrm{~m}$ height. The
Proportionality between the power output and the relative frequency distribution has also been noted.

The performance of the load factor (LF) according to the conventional time use coefficient ( Figure 15) has been associated with corresponding diagram of local duration of $\mathrm{P}^{\prime}(\mathrm{u})$. By multiplying each value of $\mathrm{LF}(\mathrm{u})$ for the duration $(\mathrm{u})$ of the corresponding specific power $\mathrm{P}^{\prime}(\mathrm{u})$ we can obtain an (EY) energy yield function of time 
of the wind turbine (Figure 16) product of a quantity characteristic of the machine (LF) for a quantity characteristic of the site $(\mathrm{u}$ $\left.\left(\mathrm{P}^{\prime}\right)\right)$.

$$
\mathrm{EY}=\mathrm{LF} \cdot \mathrm{u}\left(\mathrm{P}^{\prime}\right)
$$

It is proposed to adopt the integral yield as an indicator of the viability of the choice and the dimensioning without taking into account the value of power coefficient $\left(\mathrm{C}_{\mathrm{p}}\right)$ of a wind turbine which has the actual performance of figure 13. The maximum of variation power achieved through the energy yield (E.Y) and the best potential of the site and identifies at the same time the specific power to be taken for the project. For AL-Magrun town, the function of the energy yield assumes values less than $12 \%$, insignificant for the purposes of a power installation.

\subsection{Energy Output Analysis}

Figure 16 shows the optimal value of the integral energy yield for AL-Maqrun, which can be obtained through the corresponding value of specific power $\mathrm{P}^{\prime}$ in around $900 \mathrm{~W} / \mathrm{m}^{2} / \mathrm{y}$. It gave us the average annual energy of approximately $11 \%$ from the limit of a wind turbine generator. Therefore, the annual coefficient of the conventional use of time for AL-Magrun was about 2180 hours $\left(u=0.11^{\star} 8760\right)$ of the equivalent fully loaded operation. From above, it can be concluded that the energy yield was equal to the specific power $\left(\mathrm{P}^{\prime}\right)$ multiplying per coefficient of time (u). (EY $\left.=867.2 \mathrm{kWh} / \mathrm{m}^{2} / \mathrm{y}\right)$, multiplying per swept area(A), the annual energy output was obtained as $\mathrm{E}_{\text {out }}=4.36 \mathrm{GWh}$.

\section{ENERGY YIELD AT 80 M HEIGHT FOR OTHER SIX TURBINES}

Using the same method of production capacity accounts, we have re-calculated a number of wind turbines for various companies, with a production capacity ranging between 1650 to $2000 \mathrm{~kW}$ per hour at an altitude of 80 meters from the surface to evaluate the best in terms of productivity of electric power, especially economic feasibility study. The characteristics of these turbines and their ability curves are shown in Table 3 and Figure 17.

We can also make an initial assessment of any turbine wind intended to be used for the production of electrical power before the start of the accounts, by design figure 18, which for a way comparison can be made between the productivity of any turbine wind and choose the best or choose the turbo, which give us good production of electric power and is economically feasible.

An estimation of annual energy yield at position of AL-Maqrun meteorological mast has been done, considering a generic wind turbine of $1.65 \& 2 \mathrm{MW}$, In the power curve considering the air density is considered to be equal to $1.225 \mathrm{Kg} / \mathrm{m}^{3}$.

At $80 \mathrm{~m}$ the estimation of energy yield using Gamesa G90-2.0 MW is 6.05 GWh or 3023 equivalent hours, Vestas V82-1.65 MW is $5.13 \mathrm{GWh}$ or 3107 equivalent hours and M.Torres TWT1.65-82 is 4.39 GWh or 2660 equivalent hours. It seems a fair value in the context of a possible development of wind energy projects in the area, 
considering a value of 2400 equivalent hours as an approximate limit to consider a wind economically profitable.

While when using Vestas V80/2.0MW, the energy yield is $4.36 \mathrm{GWh}$ or 2180 equivalent hours, Gamesa G80/2000 is $4.36 \mathrm{GWh}$ or 2180 equivalent hours, M.Torres TWT1.65-77 is $3.6 \mathrm{GWh}$ or 2194 equivalent hours and De
Wind D8.2 is 4.06 GWh or 2031 equivalent hours. It does not seem a very fair value in the context of a possible development of a wind energy projects in the area (considering $2400 \mathrm{Heq}$ as a fair value). Other five turbines were tested as shown in Table 3.
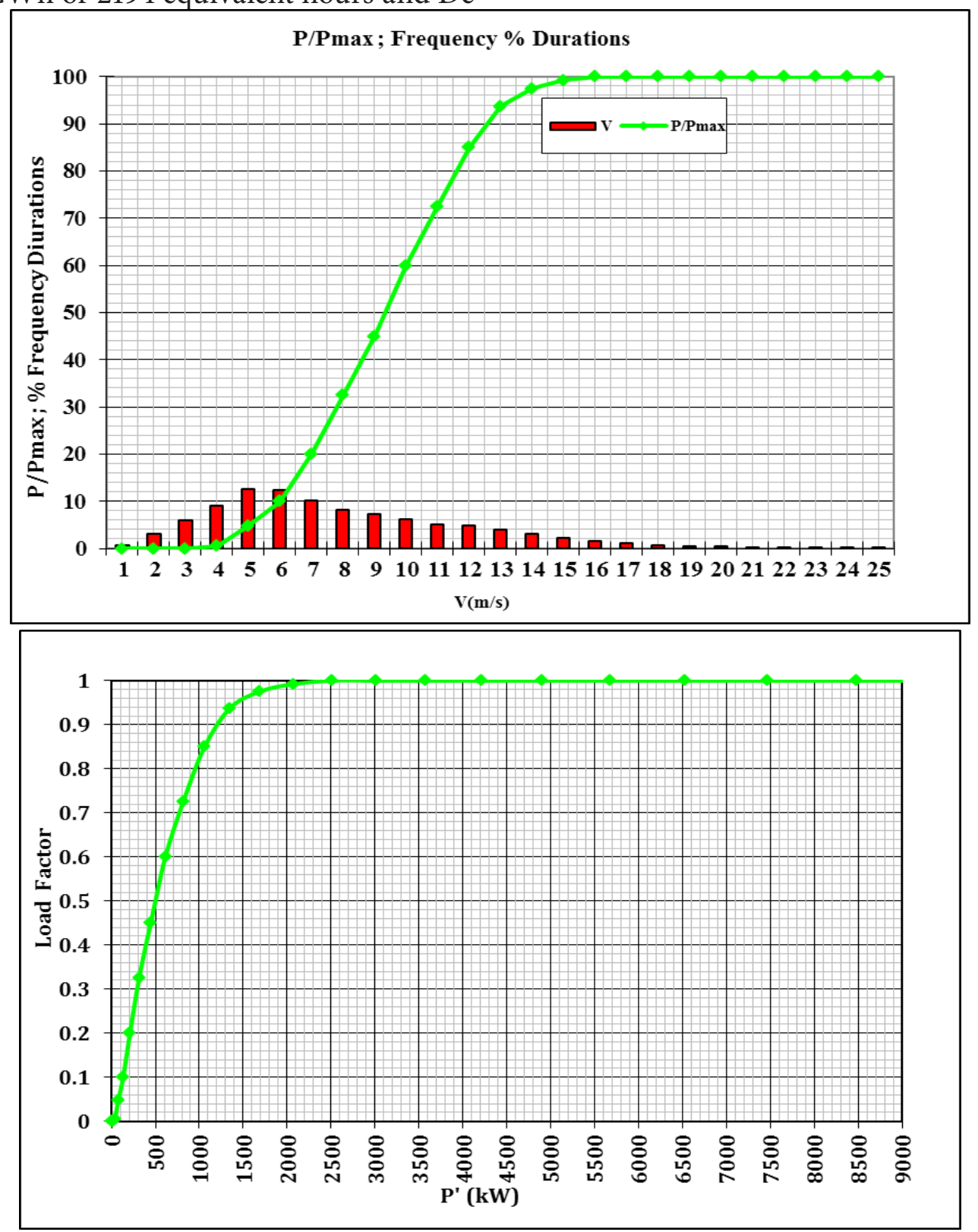

Figure (14). Load factor and distribution frequency of wind speeds 


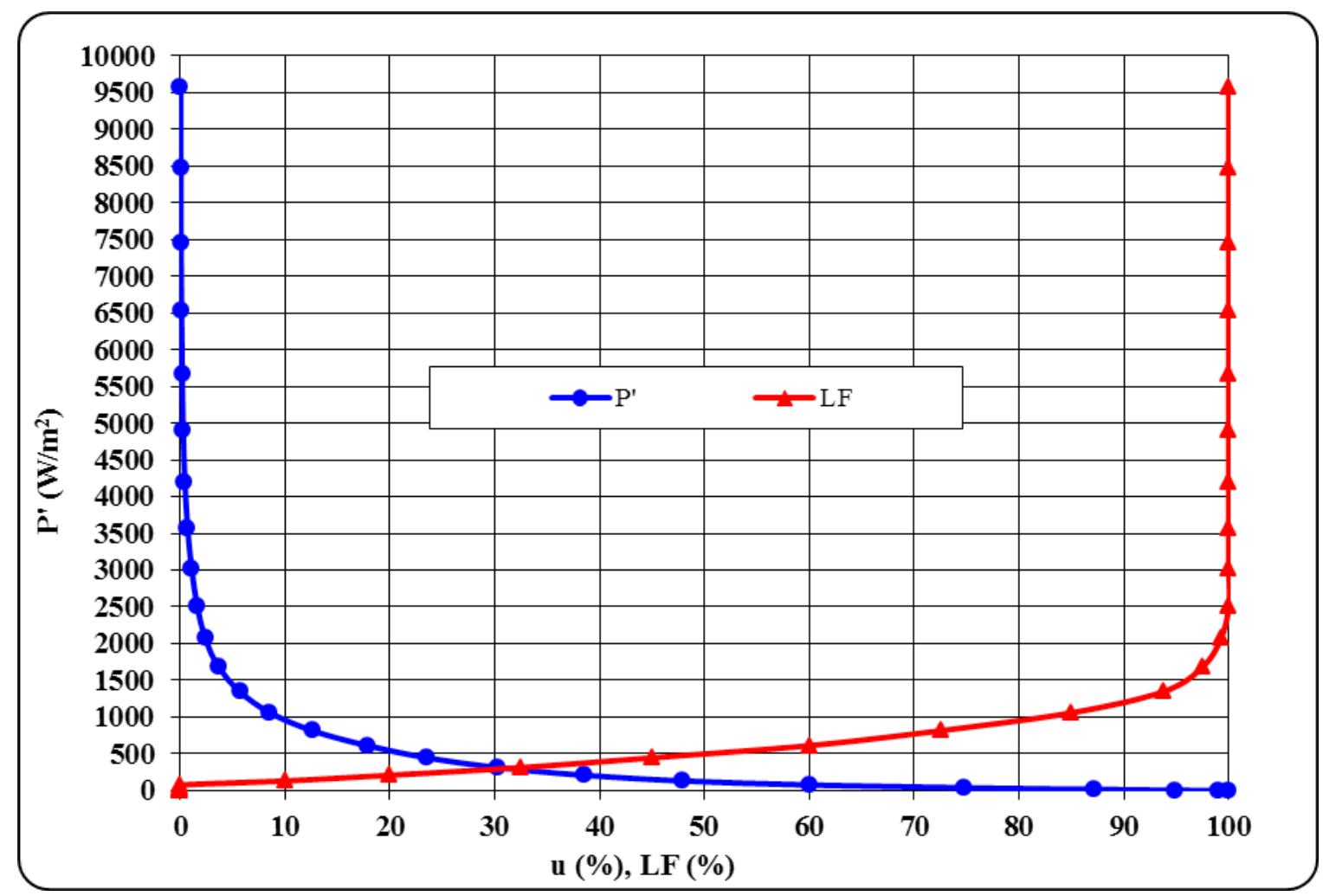

Figure (15). Specific power $\left(\mathrm{P}^{\prime}\right)$ and the load factor (LF) durations

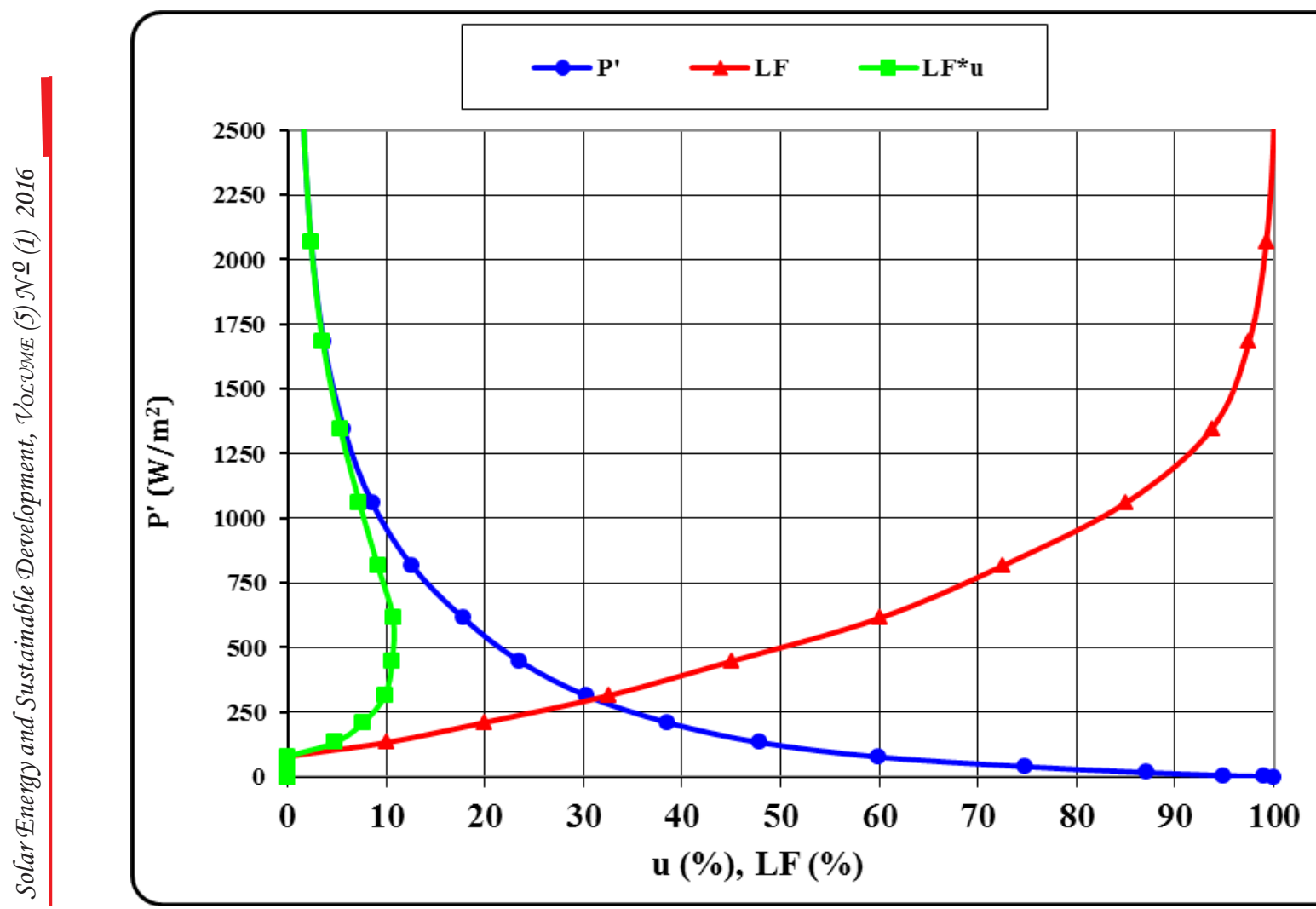

Figure (16). Specific power and amount of $\left(\mathrm{LF}^{\star} \mathrm{u}\right)$ for AL-Maqrun location 


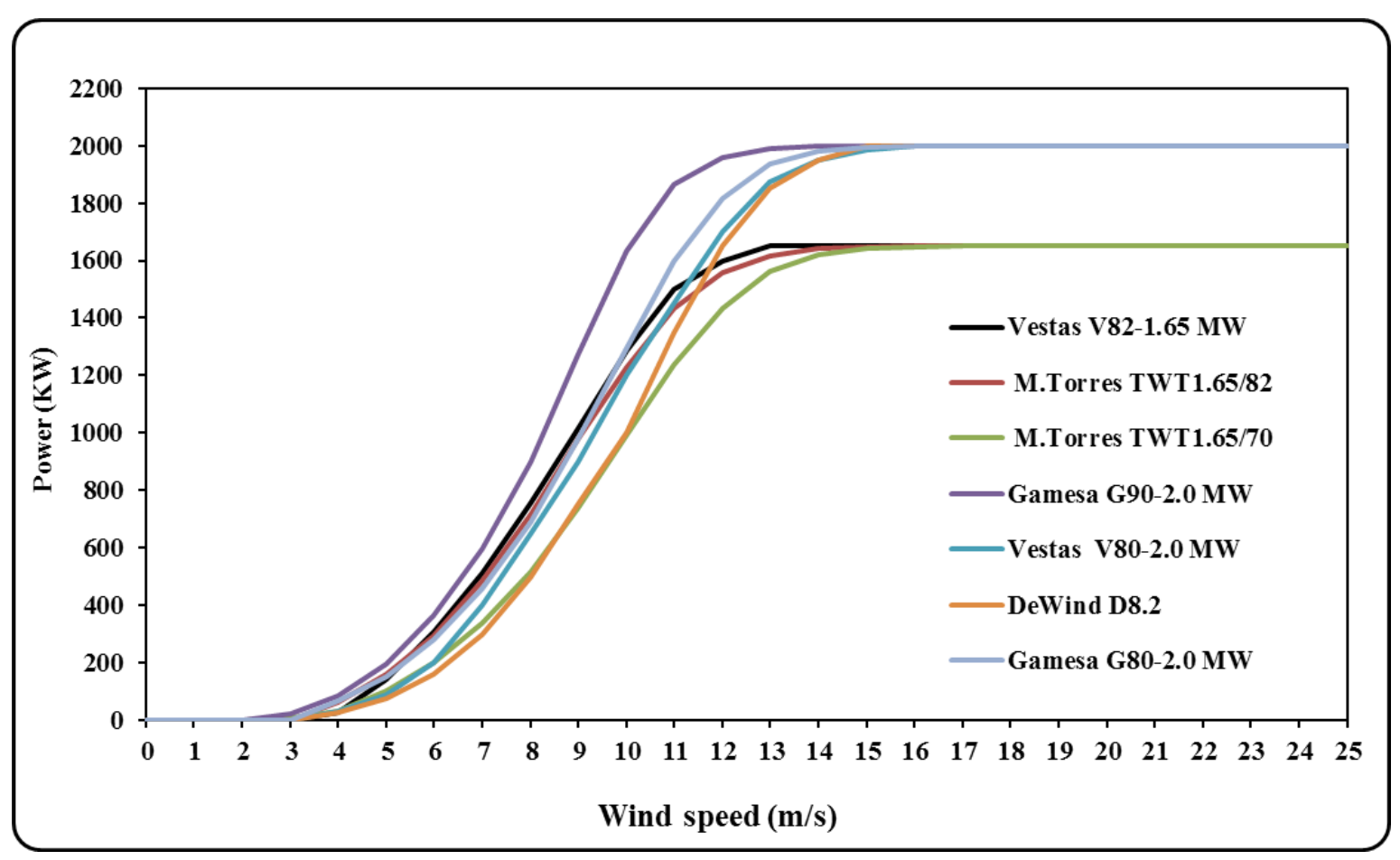

Figure (17). Power curves of wind turbines Used, [7-12]

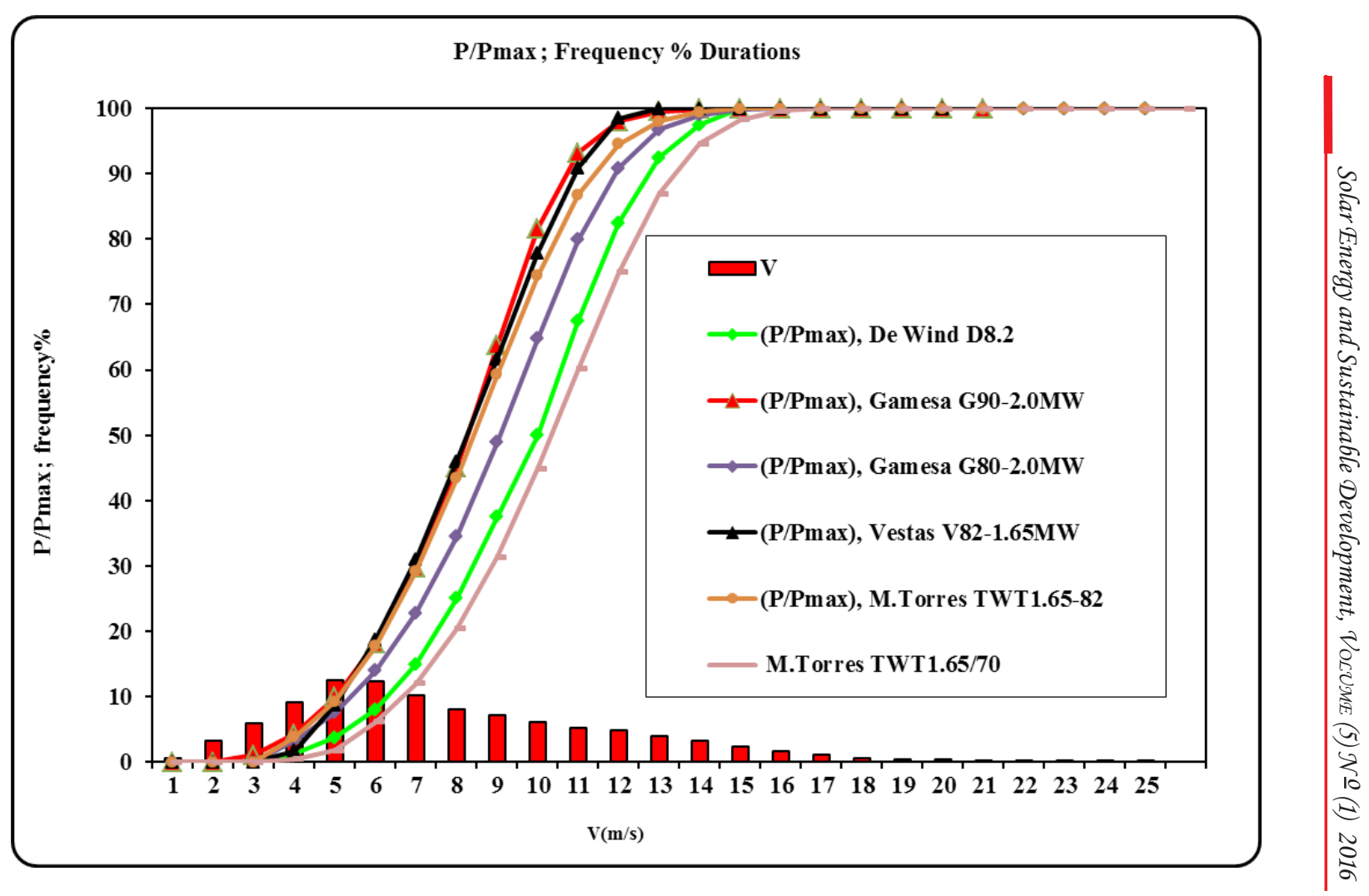

Figure (18). Load factors and distribution frequency of wind speeds for seven wind turbines used 
Table (3). Main characteristics and obtained results at air density of $1.225\left(\mathrm{~kg} / \mathrm{m}^{3}\right)$

\begin{tabular}{|c|c|c|c|c|c|c|c|c|}
\hline Turbine & $\begin{array}{l}\text { Rated } \\
\text { power } \\
{[\mathrm{MW}]}\end{array}$ & $\begin{array}{c}\text { Blade } \\
\text { flight } \\
\text { diameter } \\
\text { [m] }\end{array}$ & $\begin{array}{c}\text { Hub } \\
\text { altitude } \\
{[\mathrm{m}]}\end{array}$ & 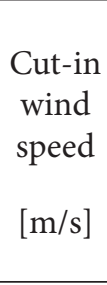 & $\begin{array}{l}\text { Rated } \\
\text { wind } \\
\text { speed } \\
{[\mathrm{m} / \mathrm{s}]}\end{array}$ & $\begin{array}{c}\text { Cut-out } \\
\text { wind } \\
\text { speed } \\
{[\mathrm{m} / \mathrm{s}]}\end{array}$ & $\begin{array}{c}\text { Production } \\
\text { [GWh] }\end{array}$ & $\begin{array}{c}\text { Production } \\
\text { [Eqh] }\end{array}$ \\
\hline $\begin{array}{c}\text { Gamesa } \\
\text { G90/2000 }\end{array}$ & 2000 & 90 & 78 & 3 & 16 & 21 & 6.05 & 3023 \\
\hline $\begin{array}{c}\text { Gamesa } \\
\text { G80/2000 }\end{array}$ & 2000 & 80 & 80 & 4 & 16 & 25 & 4.36 & 2180 \\
\hline $\begin{array}{c}\text { Vestas } \\
\text { V82/1.65 }\end{array}$ & 1650 & 82 & 80 & 3.5 & 13 & 20 & 5.13 & 3107 \\
\hline $\begin{array}{c}\text { Vestas } \\
\text { V80/2000 }\end{array}$ & 2000 & 80 & 80 & 4 & 16 & 25 & 4.36 & 2180 \\
\hline $\begin{array}{c}\text { M.Torres } \\
\text { TWT1.65-82 }\end{array}$ & 1650 & 82 & 71 & 3.5 & 13 & 25 & 4.39 & 2660 \\
\hline $\begin{array}{c}\text { M.Torres } \\
\text { TWT1.65-77 } \\
\end{array}$ & 1650 & 77 & 71 & 3 & 13 & 25 & 3.62 & 2194 \\
\hline De Wind D8.2 & 2000 & 80 & 80 & 3.5 & 3.52 & 5 & 4.06 & 2031 \\
\hline
\end{tabular}

\section{CONCLUSIONS AND}

\section{RECOMMENDATIONS}

The annual energy yield and wind direction were evaluated using the 'WindPRO' software, Excel work sheet and Ahwide's method for El-Maqrun town, considering wind turbines ranging between (1.65 MW and $2 \mathrm{MW}$ ) and the air density is equal to $1.225 \mathrm{Kg} / \mathrm{m} 3$. Seven turbines were evaluated to assess their wind energy capacity in the study area. The wind turbine (Gamesa 90/2000) recorded the highest values, equaling (6.05 GWh,3023 Eqh) and (M. Torres TWT 1.65-82) equaling (4.39 GWh , $2660 \mathrm{Eqh})$ compared to the rest of turbines studied. These values encouraged us to take advantage of wind power to achieve economic benefits. It is necessary to study all electrical systems for the future, especially the solar energy and wind energy projects, where an opportunity exists to utilize the high solar radiation levels incident and wind speed cross the country to meet a significant part of this demand, and to reduce, as much as possible, the carbon dioxide emissions. This study concluded also that the annual energy yield of wind turbines increases with the increasing for all of the following properties, hub height, rotor diameter and rated power. These variables are considered very important to obtain the best energy yield. Finally, the energy yield for AL-Maqrun town was acceptable. We recommend the use of a wind turbine which has a rated power greater than $1000 \mathrm{~kW}$ at El-Maqrun town. This evaluation is hoped to trigger the use of large wind turbines 
at the selected sites along the coasts of the Mediterranean.

\section{REFERENCES}

[1]. Libyan National Meteorological center, Meteorological Data, Tripoli.

[2]. Renewable Energy Authority of Libya, Tripoli, projects department.

[3]. Manwell, J.F., McGowan, J.G and A.L. Rogers, A.L.; "Wind Energy Explained, Theory, Design and Application", John Wiley \& Sons, USA, 2002.

[4]. Ahmed Shata, A.S., Hanitsch, R.; "Electricity generation and wind potential assessment at Hurghada", Egypt, Renewable Energy 33 (2008) 141-148.

[5]. Ahwide, F. R., Spena A. ; "Estimation and assessment of wind energy potential in some areas in Libya", presented in the 4th International Conference on Energy Management in Italy, AIGE Roma, 26-27 Maggio 2010).

[6]. Ahwide, F. R., Spena, A. and El-Kafrawy,
A. ; "Estimation of Electricity Generation in Libya using Processing Technology of Wind Available Data: The Case study in Derna", 4th International Conference on Environmental Science and Development. (ICESD 2013: January 19-20, Dubai, UAE) , 2013.

[7]. http://www.vestas.com/Files/Filer/EN/ Brochures/090821_Product-brochure-V802.0MW-06-09-EN.pdf.

[8]. http://www.vestas.com/Files/Filer/EN/ Brochures/ProductBrochureV82-1.65MW_ UK.pdf.

[9]. http://www.atp.ruhr-uni-bochum.de/coop/ upload/Dewind_D8-2_A4_small.pdf.

[10]. http://iberdrolarenewables.us.files. s3.amazonaws.com/pdf/2-Gamesa_Eolica_ G90.pdf.

[11]. http://www.gamesacorp.com/recursos/ doc/productos-servicios/aerogeneradores/ catalogo-g9x-20-mw-eng.pdf.

[12]. http://en.wind-turbine-models.com/ turbines/804-m.torres-twt-1.65-82. 